\title{
N-Acetylcysteine (D- and L-Stereoisomers) Prevents Apoptotic Death of Neuronal Cells
}

\author{
Giovanna Ferrari, ${ }^{a}$ Chao Yun Irene Yan, and Lloyd A. Greene \\ Department of Pathology and Center for Neurobiology and Behavior, Columbia University College of Physicians and \\ Surgeons, New York, New York 10032
}

In the present study we tested whether $\mathrm{N}$-acetyl-L-cysteine (LNAC) affects apoptotic death of neuronal cells caused by trophic factor deprivation. LNAC, an antioxidant, elevates intracellular levels of glutathione. We used serum-deprived PC12 cells, neuronally differentiated PC12 cells deprived of serum and NGF, and NGF-deprived neonatal sympathetic neurons. In each case LNAC prevents apoptotic DNA fragmentation and maintains long-term survival in the absence of other trophic support. Unlike NGF, LNAC does not induce or maintain neurite outgrowth or somatic hypertrophy. To rule out actions of LNAC metabolic derivatives, we assessed $\mathrm{N}$-acetyl-D-cysteine (DNAC). DNAC also prevents death of PC12 cells and sympathetic neurons. However, other antioxidants were ineffective in this regard. Since it has been hypothesized that trophic factors prevent neuronal death by either preventing or coordinating cell cycle progression, we tested whether LNAC or DNAC treatment can affect cell cycle. We found that both (but not other antioxidants) suppress proliferation and DNA synthesis by $\mathrm{PC} 12$ cells and do so at concentrations similar to those at which they prevent apoptotic death. Although the abilities of LNAC and DNAC to rescue celis from apoptosis triggered by trophic factor deprivation could derive from their direct influences on cellular responsiveness to oxidative stress, our observations raise the possibility of a mechanism involving cell cycle regulation.

[Key words: apoptosis, cell cycle, $\mathrm{N}$-acetyl-t-cysteine, PC12 cells, sympathetic neurons, cell death, NGF, N-acetylD-cysteine]

Cell death is an important feature of development (Ellis et al., 1991). This phenomenon is particularly prominent in the nervous system in which about half of all neurons produced die (Hamburger and Oppenheim, 1982; Purves and Lichtman, 1985), and sclection of surviving cells appears to be based on competition for limiting amounts of trophic factors exemplified by NGF (Oppenheim, 1991). Neurons appear to retain their de-

\footnotetext{
Received Aug. 8, 1994; revised Oct. 19, 1994; accepted Oct. 21, 1994

We thank Dr. A. Rukenstein for aid with cell culture and helpful discussion, Dr. K. Nakanishi and Mr. B. Rickman for generous assistance with circular dichroism analysis, Dr. B. Levine for helpful discussion, and Dr. R. DallaFavera for critically reading the manuscript. This work was supported by the U.S. Public Health Service (NIH-NINDS), the March of Dimes Birth Defects Foundation, and the Amyotrophic I ateral Sclerosis Association

Correspondence should be addressed to Dr. Lloyd A. Greene at the above address.

"Present address: Fidia Research Laboratories, Via Ponte della Fabbrica 3/A, Abano Terme, Italy.

Copyright (C) 1995 Society for Neuroscience $0270-6474 / 95 / 152857-10 \$ 05.00 / 0$
}

pendence on trophic factors even in the mature state (Hendry and Campbell, 1976; Rich et al., 1987), and it has been suggested that all cell types may require the continuous presence of survival-promoting agents (Raff et al., 1993).

Insight regarding the mechanism of neuronal cell death has been limited. Death triggered by withdrawal of trophic support generally appears to follow an apoptotic pathway characterized by distinct morphological changes including early chromatin condensation and subsequent nuclear disruption and by characteristic internucleosomal DNA digestion (Wyllie et al., 1980; Batistatou and Greene, 1991; Edwards et al., 1991; Deckwerth and Johnson, 1993; Edwards and Tolkovsky, 1994).

Two model neuronal systems have been extensively exploited to study the mechanisms of apoptotic death caused by loss of trophic support. One is the neuroblast-like PC12 cell model in which apoptosis is rapidly triggered by withdrawal of serum from proliferating cultures and prevented under such conditions by NGF (Greene, 1978; Batistatou and Greene, 1991; Rukenstein et al., 1991). In addition, after these cells have been induced to reach a nondividing, neuronally differentiated state by long-term NGF treatment, death can be evoked by withdrawal of serum and NGF (Greene, 1978; Batistatou and Greene, 1991; Mesner et al., 1992; Pittman et al., 1993). A complementary system is represented by sympathetic neuron cultures in which apoptotic death occurs within several days after NGF deprivation (Edwards et al., 1991; Batistatou and Greene, 1993; Deckwerth and Johnson, 1993; Edwards and Tolkovsky, 1994).

Evidence has been raised that supports several alternative mechanisms by which apoptotic death of neuronal cells occurs following withdrawal of trophic support. One model suggests that death is due to oxidative stress brought about by trophic factor withdrawal. Trophic factors have been reported both to enhance the activity of metabolic pathways that deal with oxidative stress as well as to protect cultured neurons from oxidative-stress-induced cell death (Jackson et al., 1990; Nisticó et al., 1991; Spina et al., 1992; Pan and Perez-Polo, 1993; Sampath et al., 1994). An alternative mechanism that has been suggested to account for neuronal apoptotic death is an inappropriately regulated or aborted attempt to reenter or traverse the cell cycle (Batistatou and Greene, 1993; Farinelli et al., 1993; Heintz, 1993; Ruhin et al., 1993; Freeman et al., 1994; Greene et al., 1994).

In the present study, we tested the capacity of $\mathrm{N}$-acetylcysteine (NAC) to affect apoptosis caused by withdrawal of serum and/or NGF from PC12 cells and sympathetic neurons. NAC is an antioxidant that increases intracellular glutathione, a major component of the pathways by which cells are 
protected from oxidative stress (Meister, 1988). We found that NAC effectively rescues both cell types. The efficacy of NAC in protecting cells from apoptosis generally has been interpreted within the context of a mechanism involving oxidative stress. However, we made the unanticipated observation that NAC blocks cell proliferation and DNA synthesis. This raises the possibility that NAC rescues trophic-factor-deprived cells due to its antiproliferative actions rather than to its protection from oxidative stress.

\section{Materials and Methods}

Materials. Mouse NGF was prepared from adult male submaxillary glands as previously described (Mobley et al., 1976) and was used at a concentration of $100 \mathrm{ng} / \mathrm{ml}$. $\mathrm{N}$-Acetyl-L-cysteine (Sigma) and $\mathrm{N}$-acetylD-cysteine (Research Organic Inc.) were dissolved in RPMI 1640 at a concentration of $800 \mathrm{mM}$ and diluted to the desired concentration directly in the culture medium. Circular dichroism analysis confirmed that the D-stereoisomer did not contain detectable levels of LNAC. All other reagents were purchased from Sigma Chemical Co.

Cell cultures. PC12 cells were cultured as previously described on collagen-coated dishes in RPMI 1640 medium supplemented with $10 \%$ heat-inactivated horse serum and $5 \%$ fetal bovine serum (Greene and Tischler, 1976). For the experiments in serum-free medium, cells were extensively washed in serum-free RPMI 1640 medium as previously described (Batistatou and Greene 1991; Rukenstein et al., 1991).

For survival experiments, washed cells were resuspended in RPMI 1640 medium and plated in $0.5 \mathrm{ml}$ at a density of $8-10 \times 10^{4}$ per well in 24 well plastic culture dishes coated with rat tail collagen. To feed, but to avoid loss of floating cells, fresh medium $(0.2 \mathrm{ml})$ was added to the cultures on days 1, 5, and 10. For experiments involving "primed" PC12 cells, cultures were pretreated for 1-2 weeks with NGF in RPMI 1640 medium supplemented with $1 \%$ heat-inactivated horse serum. The cells were then washed and passaged into serum-free RPMI 1640 medium as described above.

Primary cultures of dissociated sympathetic neurons were prepared from the superior cervical ganglia of postnatal day 2 or 3 rats (Lee et al., 1980). Cells were plated at a density of approximately 0.4 ganglion per well in 24 well plastic culture dishes precoated with collagen. Cultures were grown in RPMI 1640 culture medium supplemented with $10 \%$ heat-inactivated horse serum and $100 \mathrm{ng} / \mathrm{ml} \mathrm{NGF}$. Fluorodeoxyuridine $(10 \mu \mathrm{M})$ and uridine $(10 \mu \mathrm{M})$ were added on days $1-3$ and 5-7 to eliminate non-neuronal cells. To effect rapid and total NGF deprivation, the cultures were washed three times with RPMI 1640 medium containing $10 \%$ horse serum and then maintained in the same medium $(0.5 \mathrm{ml} /$ well $)$ in the presence of affinity-purified anti-NGF polyclonal rabbit antibodies (provided by Fidia Research Laboratories, Abano Terme, Italy) at a dilution of 1:250. At this dilution, the anti-NGF antibodies completely antagonize the effect of NGF $(20 \mathrm{ng} / \mathrm{ml})$ when tested on neurite regeneration of NGF-primed PC12 cells. Thereafter, cultures were fed every $2 \mathrm{~d}$.

Cell counts. For PC12 cells, the culture medium was removed to avoid loss of floating cells, centrifuged $(500 \times \mathrm{g}, 5 \mathrm{~min})$, and replaced with $0.2 \mathrm{ml}$ of a detergent-containing solution that lyses the plasma membrane but leaves the nuclei intact (Soto and Sonnenschein, 1985). The nuclei were counted in a hemacytometer. Nuclei were counted only if they were completely intact and showed an evident limiting membrane. Counts were performed on triplicate wells and are presented as means $\pm S E M$. The results are presented relative to the cell number initially plated per well (designated as 100 ).

For sympathetic neurons, neuronal cell number was determined by strip counts (Greene et al., 1990). The neuronal cell bodies, as seen by phase contrast microscopy, are round and phase bright and thus easily distinguishable in the cultures. Cells in triplicate wells were scored and the counts are presented as means \pm SEM. The results are presented relative to the cell number in NGF-treated cultures (designated as 100).

DNA fragmentation. Experiments were performed according to Edwards et al. (1991) and Batistatou and Greene (1993). In brief, PC12 cells were washed and plated $\left(4-8 \times 10^{6}\right.$ per $100 \mathrm{~mm}$ dish) in RPMI 1640 mediun with or without additives. After incubation for $3 \mathrm{hr}$ at $37^{\circ} \mathrm{C}$, the cells were triturated off the substrate, centrifuged at $800 \times g$ for $5 \mathrm{~min}$ and the pellet washed twice with ice-cold PBS $\left(\mathrm{Ca}^{2+} \mathrm{Mg}^{2+}\right.$ free). Soluble DNA was extracted and resuspended in TE buffer (10 mM Tris, pH 8; 1 mM EDTA). Subsequently, the samples were incubated with $50 \mu \mathrm{g} / \mathrm{ml} \mathrm{DNase-free} \mathrm{RNase} \mathrm{(Boehringer} \mathrm{Mannheim)} \mathrm{at} 37^{\circ} \mathrm{C}$ for 30 min. DNA samples were subjected to electrophoresis on a $1.2 \%$ agarose gel, blotted onto Gene Screen Plus Membrane (Du Pont/New England Nuclear) and analyzed with radioactive probes from digested total PC12 cell genomic DNA. Probe labeling was performed according to Sambrook et al. (1989) and hybridization according to the manufacturer's protocol (Du Pont/New England Nuclear).

${ }^{3} \mathrm{H}$-Thymidine incorporation. Replicate cultures were established in 24 well culture dishes and treated as described. At the indicated times $0.5 \mu \mathrm{Ci} /$ well of ${ }^{3} I \mathrm{I}$-thymidine (s.a. $6.7 \mathrm{Ci} / \mathrm{mmol}$, New England Nuclear) was added in $0.5 \mathrm{ml}$ of serum-free RPMI 1640 medium. After incubation for $1 \mathrm{hr}$ at $37^{\circ} \mathrm{C}$ the cultures were washed three times with ice-cold PBS, and then incubated with ice-cold $5 \%(\mathrm{w} / \mathrm{v})$ trichloroacetic acid to extract soluble ${ }^{3} \mathrm{H}$-thymidine. The acid-insoluble material was taken up in $1 \mathrm{~N} \mathrm{NaOH}$, neutralized with $1 \mathrm{~N} \mathrm{HCl}$ and subjected to liquid scintillation counting.

Glutathione measurements. Glutathione levels (GSH) were measured by the method of Tietze (1969). Briefly, $2 \times 10^{6}$ cells were washed twice with PBS, lysed with $3 \%$ perchloric acid (PCA) for $15 \mathrm{~min}$ at $4^{\circ} \mathrm{C}$, and centrifuged, and the supernatants were neutralized with $9 \mathrm{vol}$ of $\mathrm{NaH}_{2} \mathrm{PO}_{4}, 0.1 \mathrm{M}$ (5 mM EDTA), pH 7.5. Glutathione content was measured by the addition of DTNB and the reaction monitored at 412 $\mathrm{nm}$. Glutathione is expressed as a function of total protein in the cell extract. In consonance with a previous study (Pan and Perez-Polo, 1993), no GSSG was detectable in the cells by the method of Griffith (1980).

\section{Results}

LNAC promotes long-term survival of serum-deprived $\mathrm{PCI} 2$ cells

Previous studies have shown that serum-deprived PC12 cells undergo rapid death that can be prevented by NGF and other trophic agents (Greene, 1978; Rukenstein et al., 1991). To test the effect of LNAC in this system, cultures were washed free of serum and plated in RPMI 1640 medium with no additive, NGF or LNAC. As shown in Figure $1 A$ most of the untreated cells died under these conditions within two days and all died by $5 \mathrm{~d}$. In contrast, I,NAC, like NGF, promoted long term survival ( 2 weeks) of PC12 cells in serum-free medium. Maximal long-term survival-promoting activity was observed at $60 \mathrm{~mm}$ LNAC with an $\mathrm{ED}_{50}$ of approximately $30 \mathrm{~mm}$ (Fig. $1 B$ ). Cells died within $2 \mathrm{~d}$ after LNAC was withdrawn from the cultures in serum-free medium (Fig. $1 C$ ). Thus, the LNAC effect is concentration dependent and reversible.

As shown in Figure 2, LNAC-maintained cells, were phase bright, and in contrast to those without additives, the cultures did not contained cellular debris. LNAC, however, unlike NGF, did not promote either neurite outgrowth or somatic hypertrophy. Moreover, although NGF consistently supported an initial increase in cell number in serum-free medium, LNAC did not (Fig. 1A).

We next tested whether LNAC can rescue neuronally differentiated PC12 cells from death caused by NGF withdrawal in serum-free medium. Figure 3 shows that LNAC has this capacity. However, unlike NGF, LNAC does not promote neurite maintenance or regeneration (data not shown).

\section{LNAC prevents $P C 12$ cell DNA fragmentation}

Detection of internucleosomal DN $\Lambda$ fragmentation provides a sensitive means to monitor early events of apoptotic death. In PC1 2 cell cultures, such cleavage is evident within $3 \mathrm{hr}$ of serum withdrawal and can be prevented by NGF and other trophic agents (Batistatou and Greene, 1991, 1993). To determine whether LNAC inhibits apoptotic DNA fragmentation, PC12 cells were deprived of serum and incubated for $3 \mathrm{hr}$ in the presence of either different concentrations of LNAC, $100 \mathrm{ng} / \mathrm{ml}$ NGF or no additives. Figure 4 shows that LNAC, in a dose- 
A

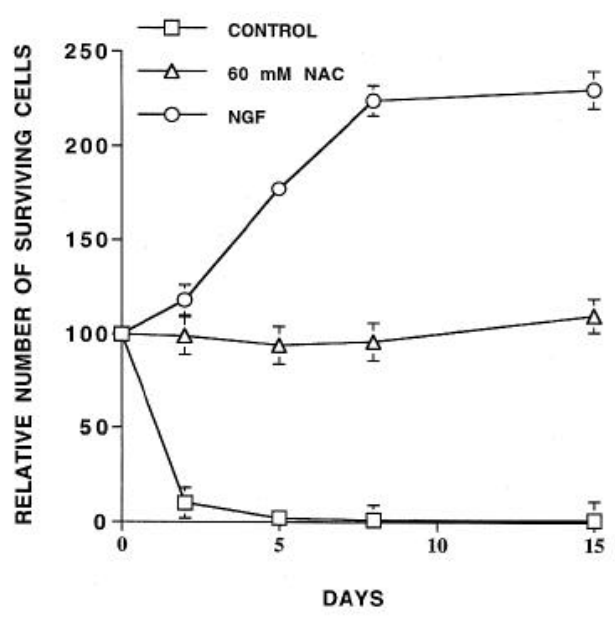

B

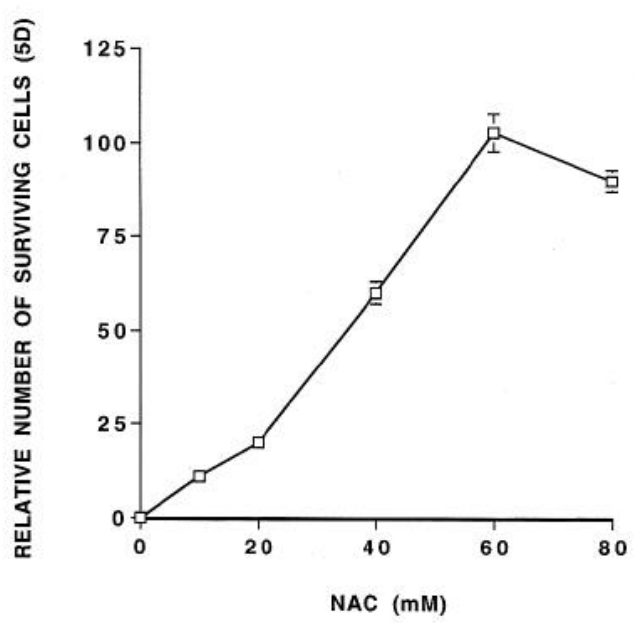

C

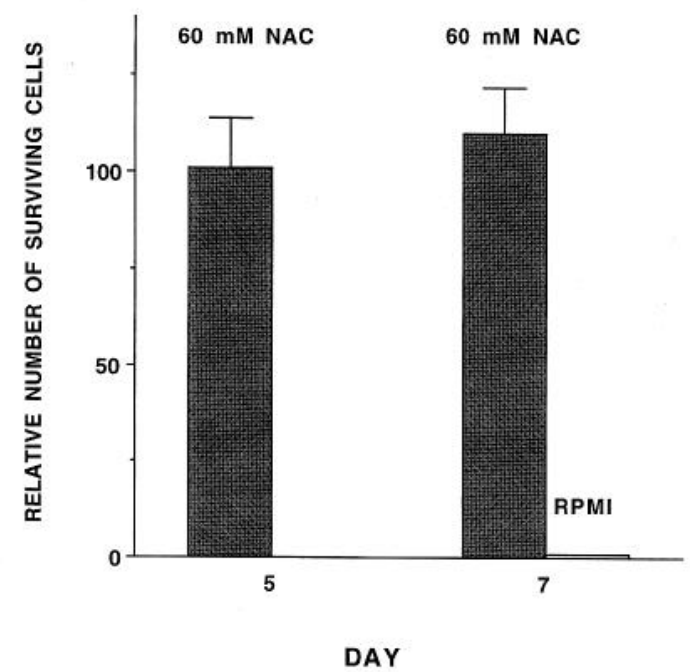

Figure 1. LNAC promotes long-term survival of $\mathrm{PC1} 2$ cells in serumfree medium. Cells were washed and plated in $0.5 \mathrm{ml}$ of RPMI 1640
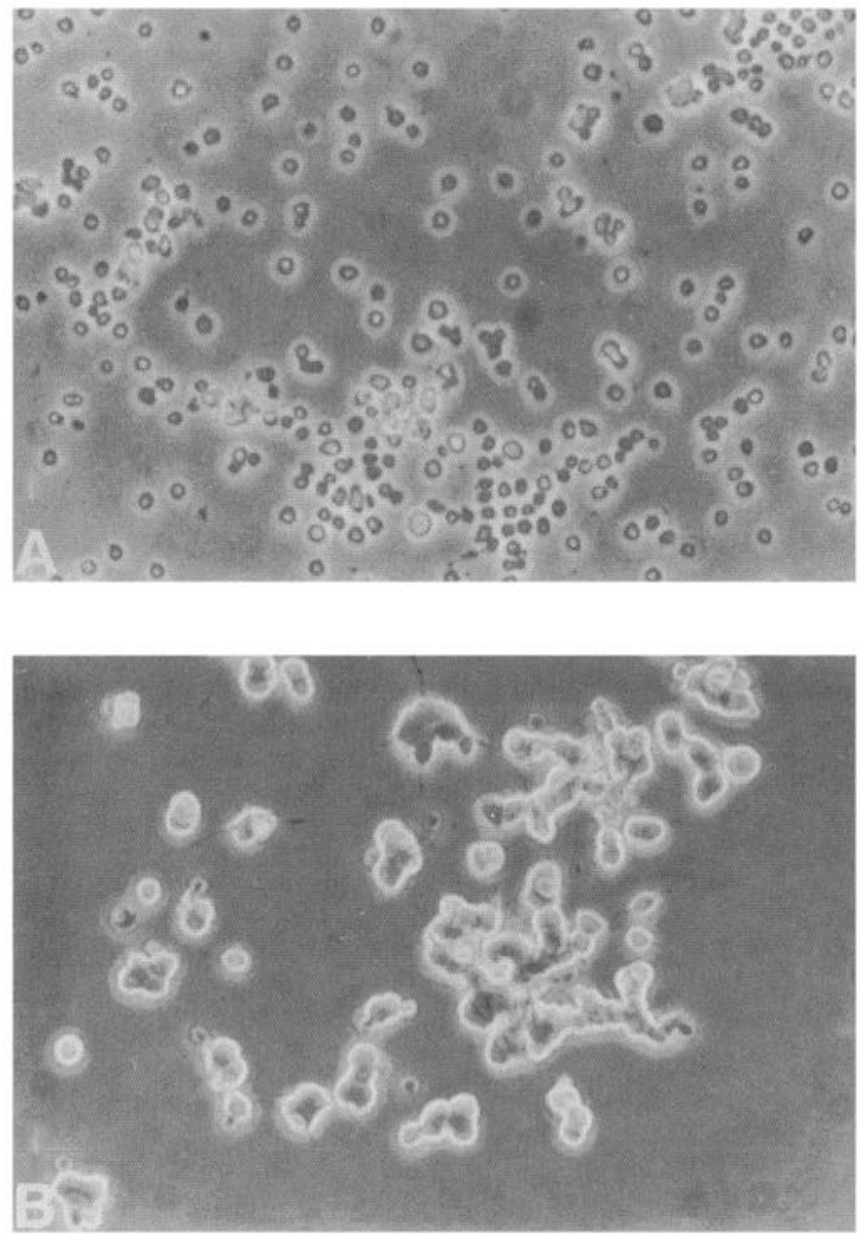

Figure 2. Morphology of PC12 cells maintained in serum-free medium with or without LNAC. PC12 cells were maintained for $8 \mathrm{~d}$ in serum-free RPMI 1640 medium either without additive $(A)$ or supplemented with $60 \mathrm{~mm}$ LNAC $(B)$. Phase-contrast optics. Magnification, $307 \times$.

dependent manner similar to that with which it rescues PC12 cells from death, prevents internucleosomal DNA cleavage.

\section{LNAC promotes long-term survival of sympathetic neurons after NGF deprivation}

Because of its efficacy in the PC12 cell paradigm, we next tested the capacity of LNAC to rescue normal neurons from trophic factor deprivation. Sympathetic neurons established in vitro in the presence of NGF rapidly die after NGF withdrawal (Levi-Montalcini and Angeletti, 1963; Martin et al., 1988) and thus represent an attractive model test system. Neonatal rat sympathetic neurons were cultured for $7 \mathrm{~d}$ with NGF in serum-containing medium and

$\leftarrow$

medium containing either no additive or the indicated agents. Viable cultures were counted on the indicated days as described in Materials and Methods. The numbers of surviving cells are presented relative to the number initially plated $\left(8-10 \times 10^{4}\right.$; designated 100$)$. A, Time course of LNAC and NGF effects on survival. Error bars represent SEM $(n=6) . B$, Dose-response curve for LNAC $(5 \mathrm{~d}$ in serum-free medium). $C$, Reversibility of LNAC effect on survival. Sister cultures, after serum deprivation, were treated with $60 \mathrm{~mm}$ LNAC for $5 \mathrm{~d}$, washed twice with RPMI and incubated for 2 more days in the presence or absence of LNAC. 


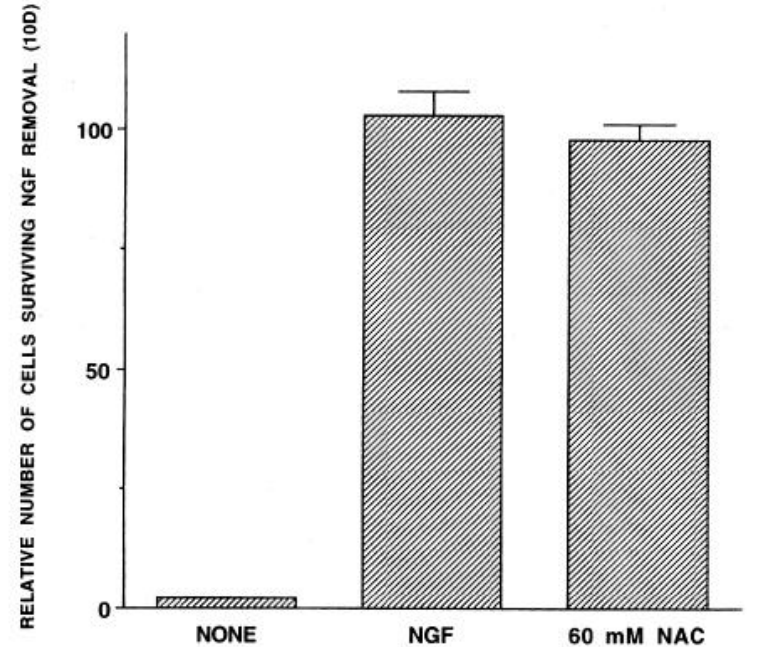

Figure 3. LNAC promotes long-term survival of NGF-primed PC12 cells in serum-free medium. Cells were pretreated with NGF in RPMI 1640 medium containing $1 \%$ HS for $10 \mathrm{~d}$, and then washed and passaged into serum-free RPMI 1640 medium and maintained for $10 \mathrm{~d}$ with the indicated additives (NONE, no additive). Cell numbers are expressed relative to those initially plated $\left(8-10 \times 10^{4}\right)$. Concentration for NGF was $100 \mathrm{ng} / \mathrm{ml}$. Error bars represent SEM $(n=3)$. Comparable results were achieved in three independent experiments.

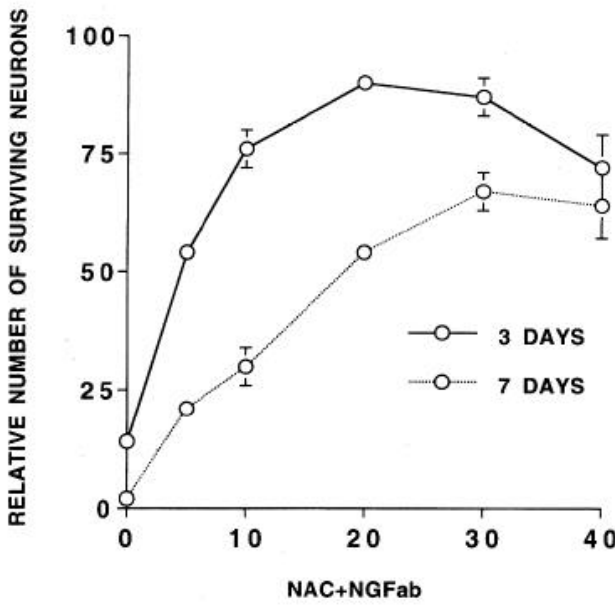

Figure 5. LNAC promotes survival of rat cultured sympathetic neurons deprived of NGF. Neurons were maintained in the presence of NGF for 1 week, deprived of the factor, and cultured for 3 or $7 \mathrm{~d}$ in the presence of anti-NGF and with or without the indicated concentrations of LNAC. Living, phase-bright neurons were counted and the values are presented relative to the number present in NGF-treated cultures (designated 100). Error bars represent SEM ( $n=3$ independent cultures). Comparable results were obtained in three independent experiments.

then were deprived of the factor by washout and treatment with anti-NGF antibodies (anti-NGF). Various concentration of LNAC were added to the cultures at the time of NGF withdrawal. As shown in Figure 5, by $3 \mathrm{~d}$ of NGF withdrawal, most of the neurons died and all died by $7 \mathrm{~d}$. In contrast, by these times, about 90 and $70 \%$ respectively, were maintained by LNAC. Figure 6 shows the morphology of neurons under the various conditions of treatment. By $3 \mathrm{~d}$ of NGF withdrawal, both the neuronal cell bodies and neurite network underwent marked degeneration and by $10 \mathrm{~d}$ only debris was present. In contrast, at the same times, LNAC-treated neurons, although smaller than NGF-treated controls, maintained phase-bright neuronal cell bodies and appeared healthy. In addition, as with neuronally differentiated $\mathrm{PC} 12$ cells, although LNAC promoted survival, it did not maintain the neurite network and the processes disintegrated. However, readdition of NGF to such cultures resulted in the reappearance of healthy neurites (data not shown).

\section{LNAC blocks cell proliferation}

Although LNAC may protect cells from oxidative stress, we considered the possibility that its capacity to rescue PC12 cells and sympathetic neurons from trophic factor withdrawal might arise from another mechanism. We noted that in contrast to PC12 cells rescued by NGF, those maintained with LNAC did not undergo initial replication in serum-free medium (Fig. 1A). Furthermore, we have shown that PC12 cells committed to die after serum deprivation continue DNA synthesis and that prevention of their entry into the cell cycle rescues them from death (Farinelli et al., 1993; Ferrari and Greene, 1994). We therefore tested whether LNAC might affect cell proliferation. For this purpose we first measured ${ }^{3} \mathrm{H}$-thymidine incorporation, an index of $\mathrm{S}$ phase activity, with $\mathrm{PC} 12$ cells grown for $1 \mathrm{~d}$ in complete medium \pm LNAC. Figure $7 A$ shows that, under these conditions, ${ }^{3} \mathrm{H}$-thymidine incorporation was inhibited by LNAC in a concentration-dependent manner. We next determined the effect of LNAC on cell proliferation and, as shown in Figure $7 B$, found
Figure 4. LNAC prevents internucleosomal cleavage of DNA. PC12 cells were washed free of serum and cultured in the presence of either no additive $(N O N E), 100 \mathrm{ng} / \mathrm{ml} \mathrm{NGF}(N G F)$, or the indicated concentrations of LNAC for $3 \mathrm{hr}$. Soluble DNA was extracted from the cells, resolved on a $1.2 \%$ agarose gel, blotted onto Gene Screen Plus membrane and analyzed as described in Materials and Methods. Comparable results were achieved in two independent experiments. 

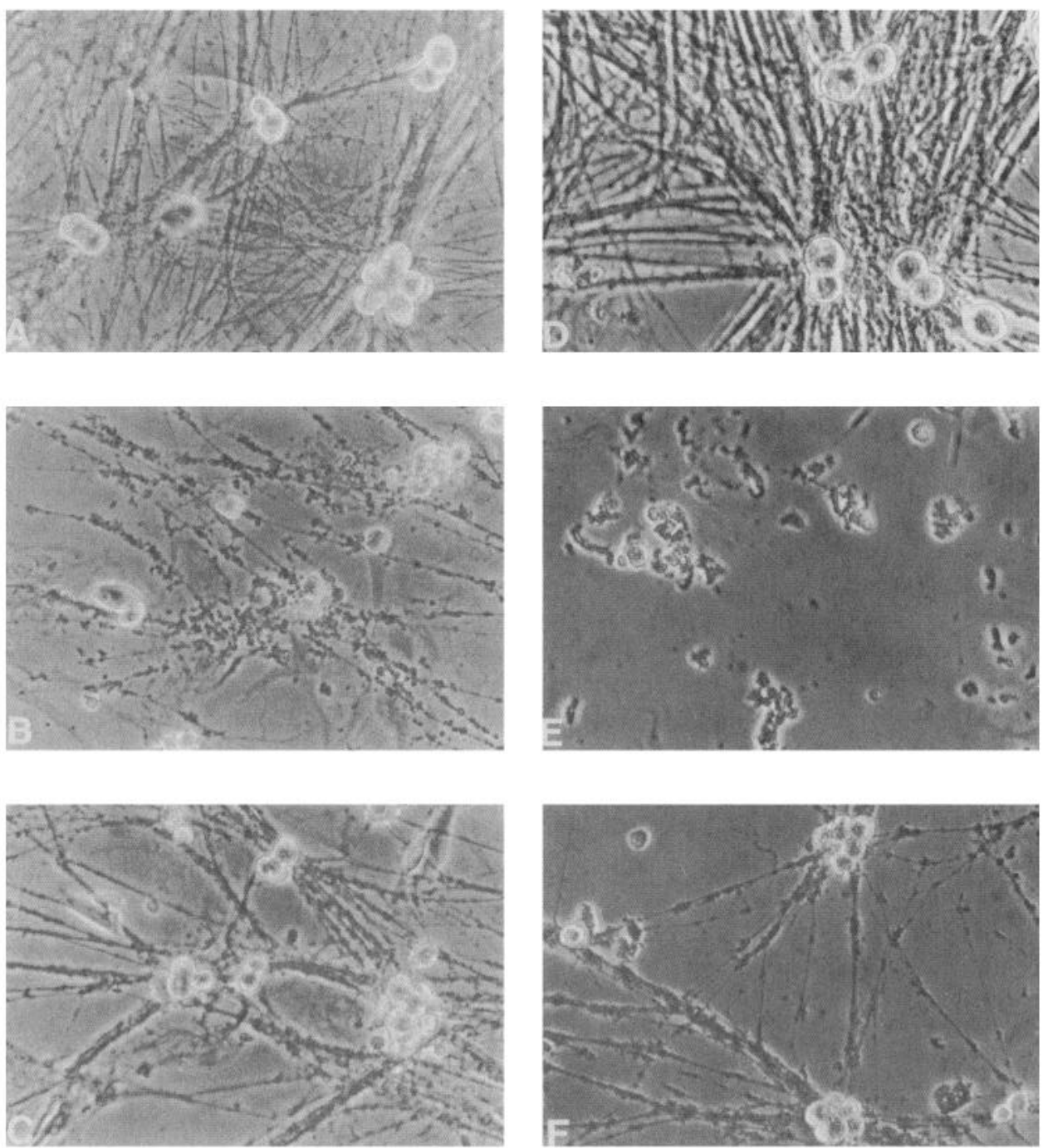

Figure 6. Effect of LNAC on cultured rat sympathetic neurons deprived of NGF. Newborn sympathetic neurons were cultured for $7 \mathrm{~d}$ with NGF and then for $3(A-C)$ or $10(D-F)$ d as follows: $A$ and $D$, with NGF present (100 $\mathrm{ng} / \mathrm{ml}) ; B$ and $E$, without NGF and with anti-NGF; $C$ and $F$, without NGF, with anti-NGF and LNAC (30 mM). Magnification, $307 \times$. that this was also suppressed in a dose-dependent manner. Despite the absence of proliferation, the cells maintained a healthy appearance and there was no cellular debris in the cultures of the type generated by cell death. Both thymidine incorporation and proliferation were nearly completely blocked by $60 \mathrm{~mm}$ LNAC with an $\mathrm{ED}_{50}$ of about $30 \mathrm{~mm}$. These dose-response relationships were strikingly similar to that at which LNAC rescues PC12 cells and sympathetic neurons from apoptotic death.

Because inhibitors of protein synthesis prevent apoptosis of sympathetic neurons (Martin et al., 1988; Edwards et al., 1991; Deckwerth and Johnson, 1993), we tested whether LNAC might affect protein synthesis in PC12 cells. We found that ${ }^{3} \mathrm{H}$ isoleucine incorporation in cultures treated with $60 \mathrm{~mm}$ LNAC was $35 \%$ less than that detected in untreated cells (data not shown). Since similar inhibition was observed at $5 \mathrm{~mm}$ LNAC, this effect, does not appear to correlate with the dose-response for promotion of survival. Also, in PC12 cell cultures, blockade of protein synthesis does not rescue the cells from apoptotic death (Rukenstein et al., 1991).

\section{DNAC has similar effects to LNAC}

Because LNAC is subject to cellular uptake and metabolic conversion (e.g., to cysteine and glutathione), we tested the effects of its stereoisomer $\mathrm{N}$-acetyl-D-cysteine (DNAC). This com- pound, while maintaining the antioxidant properties of the L-isomer, should not be metabolized. As shown in Figure 8, DNAC promotes, in a dose dependent manner, PC12 cell survival after withdrawal of trophic support. At $24 \mathrm{hr}$ of serum deprivation, a maximal effect is observed at $30 \mathrm{~mm}$ DNAC with an $\mathrm{ED}_{50}$ of approximately $20 \mathrm{~mm}$ (Fig. 8A). DNAC (30-40 mM) also promotes long term survival under these conditions (Fig. $8 B$ ). Furthermore, as LNAC, DNAC prevents death of sympathetic neurons after NGF deprivation (data not shown).

We next determined whether DNAC, as LNAC, affects cell cycle progression. The data in Figure $8, C$ and $D$, respectively, show that DNAC inhibits DNA synthesis and proliferation of PC12 cells. Moreover, the dose responses for these actions are highly similar to those with which DNAC prevents cell death (Fig. 8A).

\section{Antioxidants do not mimic the actions of NAC}

We next tested whether other antioxidants such as vitamin E $(100 \mu \mathrm{g} / \mathrm{ml})$, deferoxamine $(10 \mu \mathrm{M})$, BHA $(50 \mu \mathrm{M})$, and vitamin $\mathrm{C}(50 \mu \mathrm{M})$ share with LNAC and DNAC the ability to promote PC12 cell survival and to affect DNA synthesis. These compounds were selected because they have been reported to prevent death induced by oxidative stress of both neuronal and nonneuronal cells (Sies, 1993; Greenspan and Aruoma, 1994). As 
A

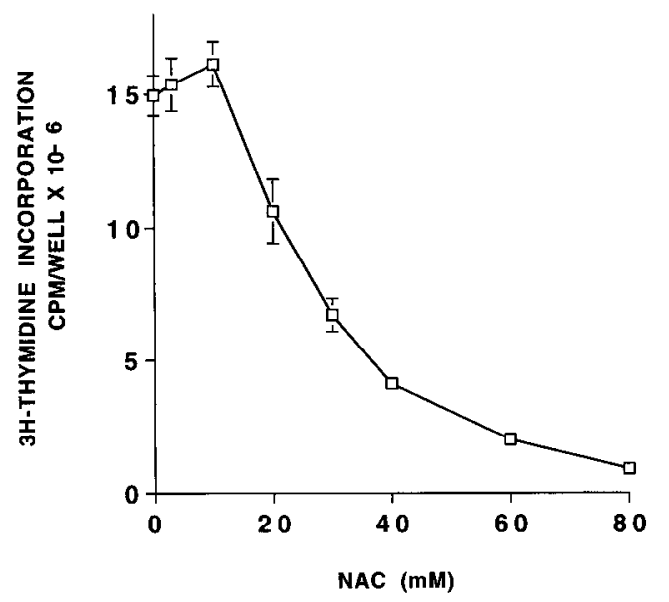

B

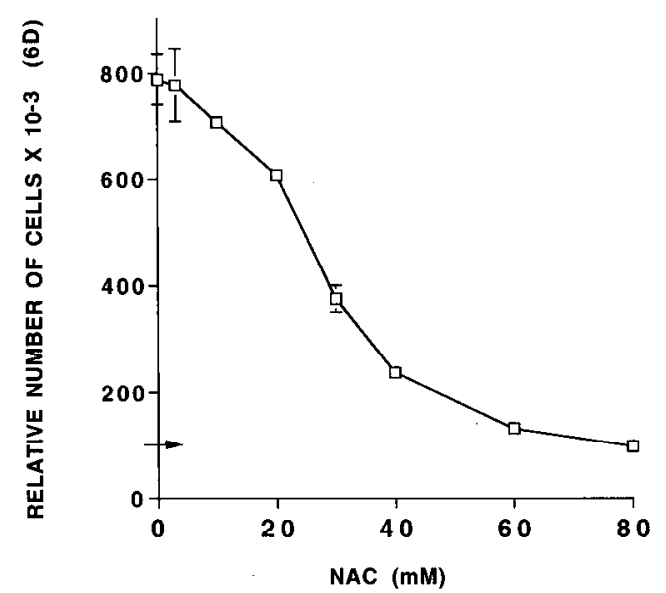

Figure 7. LNAC diminishes ${ }^{3} \mathrm{H}-$ thymidine incorporation and proliferation. Cells were plated in RPMI containing $10 \%$ HS and $5 \%$ FCS, incubated in absence or presence of the indicated additive and assessed for ${ }^{3} \mathrm{H}$-thymidine incorporation and cell number after $1(A)$ and $6 \mathrm{~d}(B)$, respectively. Arrow in $B$ indicates the number of cells plated.

shown in Figure 9, $A$ and $B$, these compounds, unlike NAC, failed to provide long-term maintenance of $\mathrm{PC} 12$ cells after trophic factor deprivation and do not affect thymidine incorporation. Examination of the survival experiment starting after $24 \mathrm{hr}$ of treatment showed no short-term effects of these concentrations of antioxidants on survival. Dose-response experiments established that the concentration used for each compound did not compromise long-term PC12 cell survival in serum-free medium supplemented with NGF (data not shown). Thus, the observed lack of survival effects were not due to toxicity.

\section{$L N A C$ and DNAC increase intracellular GSH}

In contrast to the other antioxidants we employed, a well described action of LNAC is to increase intracellular GSH (Burgunder et al., 1989). It has not been clear whether DNAC has such an effect. We therefore compared the levels of GSH in serum-deprived PC12 cells after exposure to LNAC or DNAC with those in cells maintained with either insulin or NGF (cells not exposed to NAC or growth factors die and thus cannot be evaluated for GSH levels). As shown in Figure 10, the levels of GSH in DNAC and LNAC-treated cells were similar to one another and were greatly elevated in comparison with those in cultures treated with insulin or NGF. The presence of insulin (Fig. 10) or of NGF (data not shown) did not suppress the clevation of GSH by LNAC. These findings show for the first time that DNAC can increase intracellular GSH and raise the possibility that promotion of survival by LNAC and DNAC may be causally related to their effects on intracellular GSH.

\section{Discussion}

In the present study, we show that LNAC and its nonmetabolizable stereoisomer DNAC prevent apoptotic death of neuronal cells caused by withdrawal of trophic support. The cells assessed included serum-deprived PC12 cells; PC12 cells induced into a nonproliferating, neuronally differentiated state and then deprived of NGF; and sympathetic neurons from which NGF was withdrawn.

Although LNAC shares with NGF the ability to prevent apoptotic death, it is notable that the two agents are not equivalent in their actions. Unlike NGF, LNAC does not support an initial proliferation of PC12 cells in serum-free medium, nor does it induce somatic hypertrophy. Moreover, LNAC does not promote generation or regeneration of PC12 cell neurites and does not maintain the processes of NGF-deprived sympathetic neurons. These findings confirm previous observations that separate mechanistic pathways are responsible for maintenance of survival and for promotion of neuronal differentiation (Greene, 1978; Greene et al., 1990; Batistatou and Greene, 1991, 1993; Rukenstein et al., 1991; Gagliardini et al., 1994).

There are several possible mechanisms by which NAC might prevent neuronal cell death after trophic factor deprivation. In various cell systems, apoptotic death can be delayed by suppression of protein or RNA synthesis (Martin et al., 1986; Edwards et al., 1991; Deckwerth and Johnson, 1993). However, this appears to be an unlikely mechanism for NAC, since it had only a relatively minor effect on leucine incorporation. Moreover, in the naive PC12 cell system, inhibitors of protein or RNA synthesis do not delay apoptotic death (Rukenstein et al., 1991; Batistatou and Greene, 1993).

Protection against oxidative stress represents the conventional interpretation of the means by which NAC rescues cells from apoptotic death. NAC is an antioxidant capable of direct reduction of reactive oxygen species (Aruoma et al., 1989). In addition, LNAC and, as demonstrated here, DNAC, increase intracellular levels of glutathione (GSH), an important antioxidant within cells (Meister, 1988). Several lines of evidence suggest that these properties may contribute to protection of cells from apoptosis. For example, LNAC inhibits the cytotoxic effects of TNF $\alpha$ (Chang et al., 1992), which is also reported to produce rapid oxidative stress (Asoh et al., 1989). LNAC also protects cultured neurons from glutamate analog toxicity via a mechanism interpreted to involve protection from oxidative stress ( $\mathrm{Ra}$ $\tan$ et al., 1994a). In another recent study, LNAC, like bcl-2 overexpression, partially protected a non-neuronal cell line (FL5.12) from apoptotic death induced by IL3 deprivation (Hockenbery et al., 1993). In this case, overexpression of selenoenzyme-glutathione peroxidase, which uses glutathione as a substrate in the reduction of peroxide, also prevented apoptotic death, thus suggesting that the protective effect of LNAC might be linked to its enhancement of cellular capacity to deal with 

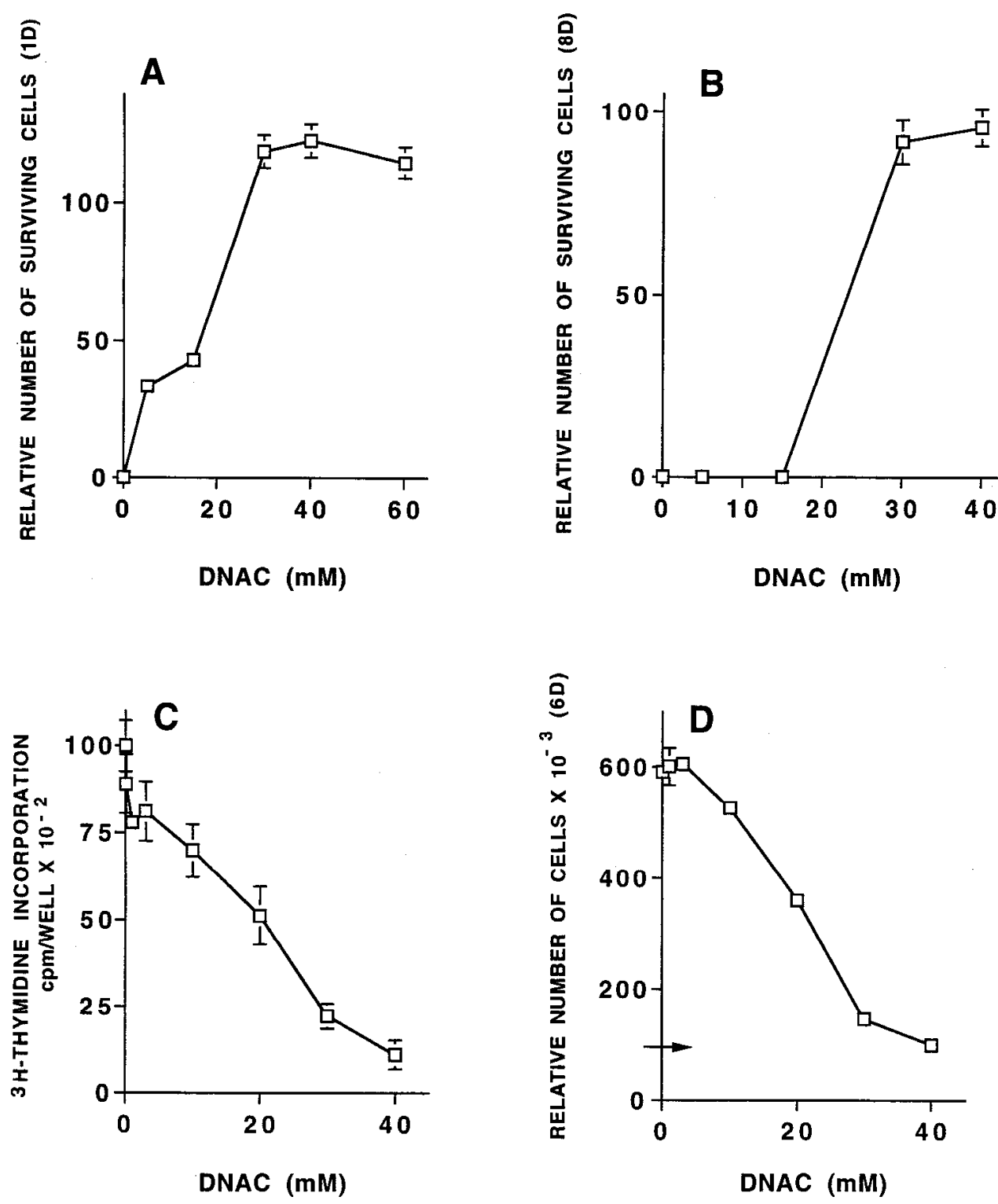

Figure 8. DNAC prevents death of PC12 cells after trophic factor deprivation and inhibits $\mathrm{PC} 12$ cell DNA synthesis and proliferation. $A$ and $B$, PC12 cells were washed free of serum and plated in RPMI-1640 in the absence or presence of the indicated concentration of DNAC. Numbers of surviving cells were assessed after $1(A)$ and $8(B) \mathrm{d}$. For day 1 , the data were normalized so that the proportion of cells surviving in the absence of additive $(32 \%$ of cells plated) was set at zero. For day 8 , no cells survived without additive. In each case, numbers of cells are expressed relative to the number plated. $C$, Effect of DNAC on ${ }^{3} \mathrm{H}-$ thymidine incorporation by PC12 cells after $1 \mathrm{~d}$ of treatment. $D$, Effect of DNAC on PC12 cell proliferation, assessed after $6 \mathrm{~d}$ of treatment. Arrow represents the number of cells plated $(100,000)$

oxidative stress. Of relevance to the potential relationship between growth factor deprivation and oxidative stress, bcl-2 overexpression both protects neuronal cells from death due to loss of trophic support (Garcia al., 1992; Batistatou et al., 1993) and from induced oxidative stress (Hockenbery et al., 1993; Kane et al., 1993). It has further been shown that NGF treatment enhances the capacity of $\mathrm{PC} 12$ cells to resist death caused by peroxidase treatment and that correlates with increases in intracellular GSH and enzymes involved in GSH metabolism (Pan and Perez-Polo, 1993; Sampath et al., 1994).

The above observations, coupled with the present findings, raise the possibility that withdrawal of trophic support from neuronal and non-neuronal cells subjects them to oxidative stress which then triggers their apoptotic death. In this scenario, NAC would prevent such death, either directly, and/or due to enhanced glutathione levels, by alleviating or preventing such stress. One aspect of our results that does not fully support this interpretation was the observation that a variety of antioxidants did not mimic the actions of NAC in our system. This would suggest either a different mechanism or that NAC protects cells from oxidative stress through a role other than as an antioxidant.
Our observations that LNAC and DNAC suppress DNA synthesis and cell proliferation and do so with similar dose responses with which they prevent apoptosis, suggest an alternative, and unanticipated mechanism for their survival-promoting actions. It has been hypothesized for both neuronal and nonneuronal cells that an attempt to enter or traverse the cell cycle in the absence of appropriate trophic factors can lead to a miscoordinated or aborted cycle which results in apoptotic death. There are a growing number of observations that support this hypothesis for both non-neuronal cells (see Lee et al., 1993, for review) as well as for both dividing neuroblasts and postmitotic neurons (Batistatou and Greene, 1993; Farinelli et al., 1993; Heintz, 1993; Rubin et al., 1993; Freeman et al., 1994; Grecnc et al., 1994). With regard to neuronal cells, for example, PC12 cells that are destined to die due to serum deprivation continue to incorporate thymidine, indicating that they are still attempting to traverse the cycle (Ferrari and Greene, 1994). In contrast, if such cells are inhibited from entering $S$ phase by induction of dominant-negative Ras (Farinelli et al., 1993; Ferrari and Greene, 1994) or by treatment with G1 phase inhibitors (Farinelli et al., 1993; Greene et al., 1994; Farinelli and Greene, un- 

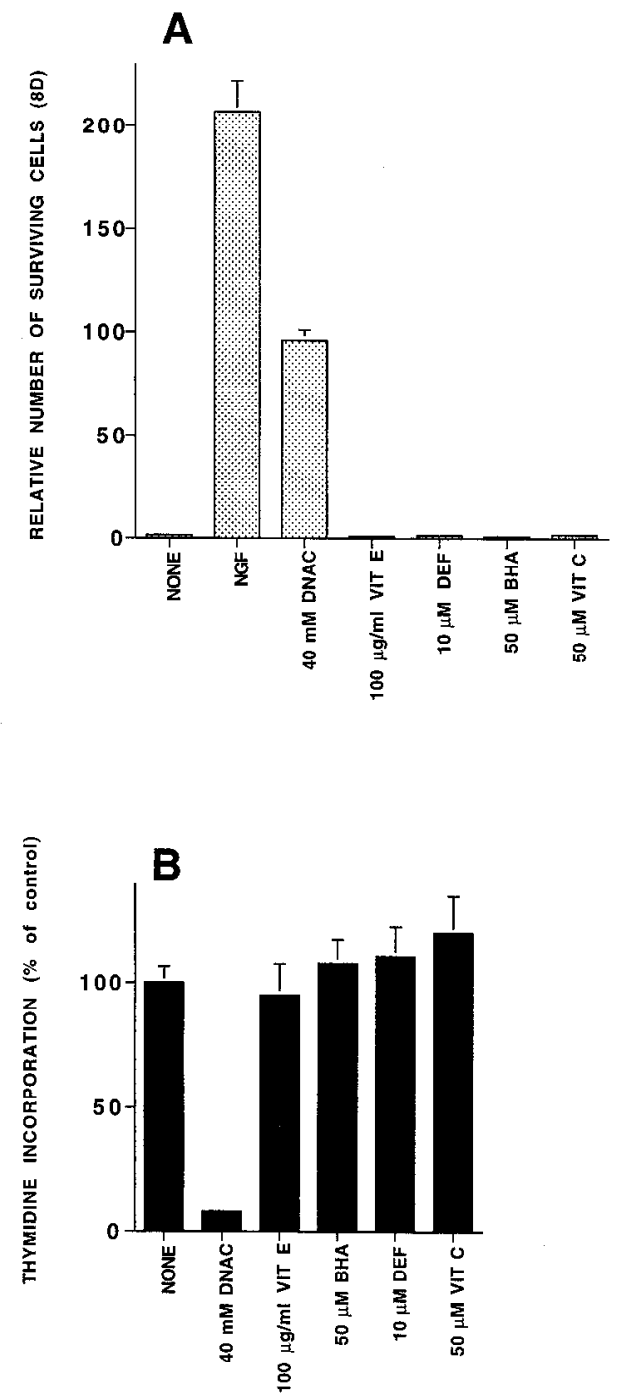

Figure 9. Other antioxidants, unlike NAC, do not affect either PC12 cell survival $(A)$ or thymidine incorporation $(B)$. PC12 cells were assessed for serum-free survival $(8 \mathrm{~d})$ and thymidine incorporation as described in Figures 1 and 7, respectively.

published observations), they are rescued from apoptotic death. In the case of nondividing, neuronally differentiated PC12 cells, when these are deprived of NGF, they reenter the cycle if serum is present (Greene and Tischler, 1976), but die if serum (a form of trophic support) is absent (Greene, 1978). Also, before death occurs due to NGF withdrawal, there occurs activation of cdc2, a protein kinase whose activity is required for cells to traverse the cycle (Brooks et al., 1993; Rubin et al., 1993). Significantly, apoptotic death caused by NGF withdrawal from neuronally differentiated $\mathrm{PC} 12$ cells is averted by induction of dominant-negative Ras (Ferrari and Greene, 1994) or by exposure to a G1 phase blocker (Farinclli and Grecne, unpublished observations). These findings are all consistent with the likelihood that NGF withdrawal triggers nonproliferating PC12 cells to reenter the cycle and that when trophic support is absent, this culminates in apoptotic death. Finally, there is support for similar behavior in postmitotic neurons. For example, in transgenic mice, targeted expression of SV40 T antigen within neuronal cells such as photoreceptors (Al-Ubaidi et al., 1992), immalure and mature Purkinje cells (Freddersen et al., 1992) and retinal horizontal cells

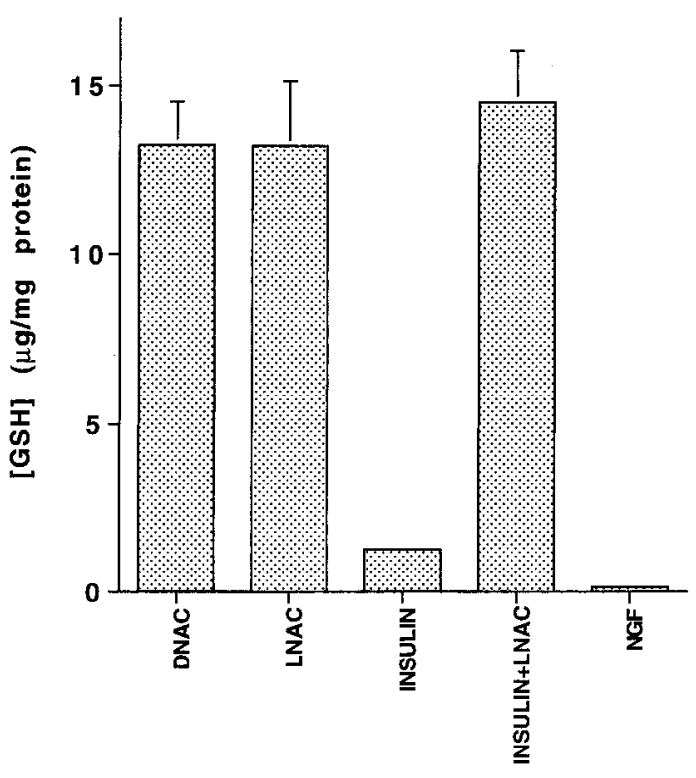

Figure 10. LNAC and DNAC increase intracellular GSH. PC12 cells were cultured for $48 \mathrm{hr}$ in serum-free medium in the presence of either $40 \mathrm{~mm}$ DNAC, $40 \mathrm{~mm}$ LNAC, $3 \mu \mathrm{M}$ insulin, insulin $+40 \mathrm{~mm}$ LNAC, or NGF. The cells were then harvested and assessed for GSH levels as described in Materials and Methods. Error bars indicate SEM $(n=3)$.

(Hammang et al., 1993) results in their death. In addition, sympathetic neurons deprived of NGF undergo induction of cyclin D1, a protein highly expressed in G1 and involved in cycle progression (Estus et al., 1993; Freeman et al., 1994).

Such considerations have led to the suggestion that neurotrophic factors such as NGF maintain survival either by permitting neuroblasts to traverse the cell cycle or by influencing neurons to differentiate and to leave and remain out of the cycle (Greene et al., 1994). Conversely, according to this model, withdrawal of trophic support from cycling neuroblasts, as with proliferating non-neuronal cells, leads to an uncoordinated attempt at proliferation and death; similarly neurotrophic factor withdrawal from noncycling neurons or from neuronally differentiated PC12 cells in serum-free medium causes an inappropriate attempt to leave quiescence which triggers apoptosis (Batistatou and Greene, 1993; Rubin et al., 1993; Freeman et al., 1994; Greene et al., 1994). On the basis of these hypotheses and observations, the capacity of NAC to protect neuronal cells from apoptotic death triggered by withdrawal of trophic support can be explained by its ability to keep them from entering or traversing the cycle. A propos to this, our recent observations (G. Ferrari, K. Cechova, R. Dalla-Favera, and L. A. Greene, unpublished observations) indicate that NAC also blocks proliferation, thymidine incorporation and apoptotic death by non-neuronal cells.

Irrespective of the final mechanism by which NAC prevents neuronal cell death caused by trophic factor withdrawal, the present data point to the possible involvement of GSH. Both LNAC and, unexpectedly, DNAC greatly increased intracellular GSH levels. It has been suggested that LNAC increases intracellular GSH either by being converted to cysteine (Burguder et al., 1989), a precursor of GSH, or by reducing extracellular cystine to cysteine which is more efficiently transported into cells (Issels et al., 1988). Since DNAC should not be metabolized, our findings favor the latter possibility. Of further relevance, it was recently reported (Ratan et al., 1994a) that inhibitors of 
protein and RNA synthesis, which protect neurons from apoptosis caused by trophic factor withdrawal (Martin et al., 1988) and oxidative stress (Ratan et al., 1994a,b), substantially increase intracellular GSH. Coupled with the lack of effect of other antioxidants in our system, these considerations suggest that it will be important to determine whether elevated GSH plays a direct role in preventing neuronal apoptosis following loss of trophic support.

In summary, we show that LNAC and DNAC protect neuronal cells from apoptotic death brought about by trophic factor deprivation. Although the conventional interpretation of NAC actions suggests a mechanism involving oxidative stress, our novel findings regarding the antiproliferative activity of NAC may be taken to support the cell cycle hypothesis. Finally, it is worth considering the viewpoint that the two mechanisms are not mutually exclusive in that there may be functional cross-talk between the means by which cells respond to oxidative stress and by which they regulate cell cycle progression.

\section{Note added in press}

After submission of this work, the following article appeared: Mayer and Noble (1994).

\section{References}

Al-Ubaidi MR, Hollyfield JG, Overbeek PA, Baher W (1992) Photoreceptor degeneration induced by the expression of simian virus 40 large tumor antigen in the retina of transgenic mice. Proc Natl Acad Sci USA 89:1194-1198.

Aruoma OI, Halliwell B, Hoey BM, Butler J (1989) The antioxidant action of $N$-acetylcysteine, its reaction with hydrogen peroxide, hydroxyl radical, superoxide and hypochlorous acid. Free Radical Biol Med 6:593-597.

Asoh K, Watanabe Y, Mizoguchi H, Mawatari M, Ono M, Kohno K, Kuwano M (1989) Induction of manganese superoxide dismutase by tumor necrosis factor in human breast cancer MCF-7 cell line and its TNF-resistant variant. Biochem Biophys Res Commun 162:794-801.

Batistatou A, Greene LA (1991) Aurintricarboxylic acid rescues PC12 cells and sympathetic neurons from cell death caused by nerve growth factor deprivation: correlation with suppression of endonuclease activity. J Cell Biol 115:161-471.

Batistatou A, Greene LA (1993) Internucleosomal DNA cleavage and neuronal cell survival/death. J Cell Biol 122:523-532.

Batistatou A, Merry DE, Korsmeyer SJ, Greene LA (1993) Bcl-2 affects survival but not neuronal differentiation of PC12 cells. J Neurosci 13:4433-4428.

Brooks SF, Gibson LA, Rubin LL (1993) Apoptosis induced by NGFwithdrawal from differentiated $\mathrm{PC} 12$ cells involves activation of p34 cdk2 kinase. Soc Neurosci Abstr 1:885.

Burgunder JM, Varriale A, Lauterburg BH (1989) Effect of $\mathrm{N}$-acetylcysteine on plasma cysteine and glutathione following paracetamol administration. Eur $\mathbf{J}$ Clin Pharmacol 36:127-131.

Chang DJ, Ringold GM, Heller RA (1992) Cell killing induction of manganous superoxide dismutase by tumor necrosis factor- $\alpha$ is mediated by lipoxygenase metabolites of arachidonic acid. Biochem Biophys Res Commun 188:538-546.

Deckwerth TL, Johnson EM Jr (1993) Temporal analysis of events associated with programmed cell death (apoptosis) of sympathetic neurons deprived of nerve growth factor (NGF). J Cell Biol 123: $1207-1222$.

Edwards SN, Tolkovsky AM (1994) Characterization of apoptosis in cultured rat sympathetic neurons after nerve growth factor withdrawal. J Cell Biol 124:537-546.

Edwards SN, Buckmaster AE, Tolkovsky AM (1991) The death program in cultured sympathetic neurons can be suppressed at the posttranslational level by nerve growth factor, cyclic AMP and depolarization. J Neurochem 57:2140-2143.

Ellis RE, Yuan J, Horvitz RH (1991) Mechanisms and functions of cell death. Annu Rev Cell Biol 7:663-698.

Estus S, Freeman RS, Johnson EM Jr (1993) Temporal cascade of gene induction accompanying programmed neuronal cell death. Soc Neurosci Abstr 19:1.634.

Farinelli S, Ferrari G, Greene LA (1993) A possible link between the cell cycle and apoptosis of PC12 cells. Soc Neurosci Abstr 19:1.885.

Ferrari G, Greene LA (1994) Proliferative inhibition by dominant-negative ras rescues naive and neuronally-differentiated PC12 cells from apoptotic death. EMBO J, in press.

Ferrari G, Batistatou A, Greene LA (1993) Gangliosides rescue neuronal cells from death after neurotrophic factor deprivation. J Neurosci 13:1879-1887.

Freddersen RM, Ehlenfeldt R, Yunis WS, Clark HB, Orr HT (1992) Disrupted cerebellar cortical development and progressive degeneration of Purkinje cells in SV40 T antigen transgenic mice. Neuron 9:955-966.

Freeman RF, Estus S, Johnson EM Jr (1994) Analysis of cell-related gene expression in postmitotic neurons: selective induction of Cyclin Dl during programmed cell death. Neuron 12:343-355.

Gagliardini V, Fernandez P-A, Lee RKK, Drexler HCA, Rotello RJ, Fishman MC, Yuan J (1994) Prevention of vertebrate neuronal death by the $\mathrm{crmA}$ gene. Science $263: 826-828$.

Garcia I, Martinou I, Tsujimoto Y, Martinou JC (1992) Prevention of programmed cell death of sympathetic neurons by the bcl-2 protooncogene. Science 258:302-304.

Greene LA (1978) Nerve growth factor prevents the death and stimulates neuronal differentiation of clonal $\mathrm{PC} 12$ pheochromocytoma cells in serum-free medium. J Cell Biol 78:747-755.

Greene LA, Tischler AS (1976) Establishment of a noradrenergic clonal line of rat adrenal pheochromocytoma cells which respond to nerve growth factor. Proc Natl Acad Sci USA 73:2424-2428.

Greene LA, Volonté C, Chalazonitis A (1990) Purine analogs inhibit nerve growth factor-promoted neurite outgrowth by sympathetic and sensory neurons. J Neurosci 10:1479-1485.

Greene LA, Ferrari G, Farinelli SE (1994) Regulation of apoptotic neuronal death by neurotrophic factors: a cell-cycle-related mechanism? Perspect Dev Neurobiol, in press

Greenspan HC, Aruoma OI (1994) Oxidative stress and apoptosis in HIV infection: a role for plant-derived metabolites with synergistic antioxidant activity. Immunol Today 15:209-213.

Griffith OW (1980) Determination of glutathione and glutathione disulfide using glutathione reductase and 2-vinylpyridine. Anal Biochem 106:207-212.

Hamburger V, Oppenheim RW (1982) Naturally occurring neuronal death in vertebrates. Neurosci Commun 1:39-55.

Hammang JP, Behringer RR, Baetge EE, Brinster RD, Messing A (1993) Oncogene expression in retinal horizontal cells of transgenic mice results in a cascade of neurodegeneration. Neuron 10:11971209.

Heintz N (1993) Cell death and the cell cycle: a relationship between transformation and neurodegeneration? Trends Biochem Sci 18:157159.

Hendry IA, Campbell J (1976) Morphometric analysis of rat superior cervical ganglion after axotomy and nerve growth factor treatment. J Neurocytol 5:351-360.

Hockenbery DM, Zoltan NO, Xiao-Ming Y, Curt LM, Korsmeyer SJ (1993) $\mathrm{Bcl}-2$ functions in an antioxidant pathway to prevent apoptosis. Cell 75:241-251.

Issel RD, Nagele A, Eckert K-G, Wilmanns W (1988) Promotion of cystine uptake and its utilization for glutathione biosynthesis induced by cysteamine and $N$-acetylcysteine. Biochem Pharmacol 37:881888

Jackson GR, Werrbach-Polo K, Perez-Polo R (1990) Role of nerve growth factor in oxidant-antioxidant balance and neuronal injury. II. A conditioning lesion paradigm. J Neurosci Res 25:369-374.

Kane DJ, Sarafian TA, Anton R, Hahn H, Gralla EB, Valentine JS, Ord T, Bredesen DE (1993) Bcl-2 inhibition of neural death: decreased generation of reactive oxygen species. Science 262:1274-1277.

Lee S, Christakos S, Small MB (1993) Apoptosis and signal transduction: clues to a molecular mechanism. Curr Opin Neurobiol 5:286291.

Lee VM, Shelanski ML, Greene LA (1980) Characterization of antisera raised against cultured rat sympathetic neurons. Neuroscience 5:2239-2245.

Levi-Montalcini R, Angeletti PU (1963) Essential role of the nerve growth factor in the survival and maintenance of dissociated sensory and sympathetic embryonic nerve cells in vitro. Dev Biol 7:653-659. 
Martin D, Schmidt R, Di Stefano P, Lowry O, Carter J, Johnson EM Jr (1988) Inhibitors of protein synthesis and RNA synthesis prevent neuronal death caused by nerve growth factor deprivation. J Cell Biol 106:829-844.

Mayer M, Noble M (1994) N-Acetyl-L-cysteine is a pluripotent protector against cell death and enhancer of trophic factor-mediated cell survival in vitro. Proc Natl $\Lambda$ cad Sci USA 91:7496-7500.

Meister A (1988) Glutathione metabolism and its selective modification. J Biol Chem 263:17205-17208.

Mesner PW, Winters TR, Green SH (1992) Nerve growth factor-withdrawal induced cell death in neuronal PC12 cells resembles that in sympathetic neurons. J Cell Biol 119:1669-1680.

Mobley WC, Schenker A, Shooter EM (1976) Characterization and isolation of proteolytically modified nerve growth factor. Biochemistry $15: 5543-5552$.

Nisticó G, Ciriolo MR, Fiskin K, Iannone M, Demartino A, Rotilio A (1991) NGF restores decrease in catalase and increases glutathione peroxidase activity in the brain of aged rats. Neurosci Lett 130:117119.

Oppenheim RW (1991) Cell death during development of the nervous system. Annu Rev Neurosci 14:453-501.

Pan Z, Perez-Polo R (1993) Role of nerve growth factor in oxidant homeostasis: glutathione metabolism. J Neurochem 61:1713-1721.

Pittman RN, Wang S, Di Benedetto AJ, Mills J (1993) $\Lambda$ system for characterizing cellular and molecular events in programmed neuronal cell death. J Neurosci 13:3669-3680.

Purves D, Lichtman JW (1985) Neuronal death during development. In: Principles of neural development, pp 131-154. Sunderland, MA: Sinauer.

Raff MC, Barres BA, Burne JF, Coles HS, Ishizaki Y, Jacobson MD (1993) Programmed cell death and the control of cell survival: lessons from the nervous system. Science 262:695-700.
Ratan RR, Murphy TH, Baraban JM (1994a) Oxidative stress induces apoptosis in embryonic cortical neurons. J Neurochem 62:376-379.

Ratan RR, Murphy TM, Baraban JM (1994b) Macromolecular synthesis inhibitors prevent oxidative stress induced apoptosis in embryonic cortical neurons by shunting cysteine from protein synthesis to glutathione. J Neurosci 14:4385-4392.

Rich KM, Luszcynski JR, Osborne PA, Johnson EM Jr (1987) Nerve growth factor protects adult sensory neurons from cell death and atrophy caused by nerve injury. J Neurocytol 16:261-268.

Rubin LL, Philpott KL, Brooks SF (1993) The cell cycle and cell death. Curr Biol 3:391-394.

Rukenstein A, Rydel RE, Greene LA (1991) Multiple agents rescue PC12 cells from serum-free cell death by translation- and transcription-independent mechanisms. J Neurosci 11:2552-2563

Sampath D, Jackson GR, Werrbach-Perez K, Perez-Polo RJ (1994) Effects of nerve growth factor on glutathione peroxidase and catalase in PC12 cells. J Neurochem 62:2476-2479.

Sies H (1993) Strategies of antioxidant defense. Eur J Biochem 215 : 213-219.

Soto AM, Sonnenschein C (1985) The role of estrogens on the proliferation of human breast tumor cells (MCF-7). J Steroid Biochem 23: 87-94.

Spina MB, Squinto SP, Miller J, Lindsay RM, Hyman C (1992) Brainderived neurotrophic factor protects dopamine neurons against 6-hydroxydopamine and $\mathrm{N}$-methyl-4-phenyl-piridinium ion toxicity: involvement of the glutathione system. J Neurochem 59:99-106.

Tietze F (1969) Enzymic method for quantitative determination of nanogram amounts of total and oxidized glutathione: application to mammalian blood and other tissue. Anal Biochem 27:502-522.

Wyllie AH, Kerr JFR, Currie AR (1980) Cell death: the significance of apoptosis. Int Rev Cytol 68:251-306. 